\title{
Article
}

\section{Internal communication education: A historical study}

\author{
Welch, Mary \\ Available at http://clok.uclan.ac.uk/11979/ \\ Welch, Mary (2015) Internal communication education: A historical study. \\ Journal of Communication Management, 19 (4). pp. 388-405. ISSN 1363-254X
}

It is advisable to refer to the publisher's version if you intend to cite from the work. http://dx.doi.org/10.1108/JCOM-09-2014-0053

For more information about UCLan's research in this area go to http://www.uclan.ac.uk/researchgroups/ and search for <name of research Group>.

For information about Research generally at UCLan please go to http://www.uclan.ac.uk/research/

All outputs in CLoK are protected by Intellectual Property Rights law, including Copyright law. Copyright, IPR and Moral Rights for the works on this site are retained by the individual authors and/or other copyright owners. Terms and conditions for use of this material are defined in the policies page.

\section{CLoK}

Central Lancashire online Knowledge www.clok.uclan.ac.uk

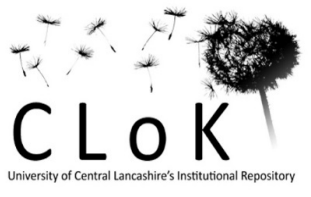


Pre-publication version of:

Welch, M. (2015) Internal communication education: A historical study.

Journal of Communication Management. Vol. 19 No. 4 pp. 388-405.

http://dx.doi.org/10.1108/JCOM-09-2014-0053

Journal of Communication Management

Internal communication education: A historical study

Author Details:

Dr Mary Welch

University of Central Lancashire, UK

mwelch@uclan.ac.uk

\section{Author biography:}

Dr Mary Welch is a Senior Lecturer in Communication Management at the University of Central Lancashire (UCLan). She has a PhD in internal communication (Manchester Business School, 2008) an MSc in marketing (UMIST, 2000) and a BA Hons in social studies (University of Liverpool, 1991). She became an academic in 2001 following a career in public relations and corporate communication management in the not-for-profit and public sectors. Her research interests and publications focus on internal communication and its implications for employee engagement. 


\begin{abstract}
Purpose

This historical analysis investigates treatment of the important discipline of internal communication in a number of globally influential public relations education frameworks over time. The paper aims to develop insight with the potential to inform future education and professional development programmes.

\section{Design / Methodology / Approach}

The conceptual framework for the study is set via discussion of the historical approach, internal communication, professionalization and knowledge. The historical critical analysis research methodology is used to study data sources including professional body reports and archival documentation. Deductive and inductive coding is combined with template analysis to ensure rigorous qualitative data analysis.
\end{abstract}

\title{
Findings
}

The study finds inconsistent treatment of the internal communication discipline in public relations education frameworks over time. Distinct inclusion was found in early frameworks, clear recognition of the growing importance of internal communication was evident in later guidelines, but the study discovers that the discipline has been excluded from recent frameworks.

\section{Research limitations / implications}

While the study draws on relevant data sources credited with international influence, it is limited to sources published in English.

\section{Practical implications}

Practical educational and methodological implications of the research are discussed along with avenues for further research including surveys or qualitative research to investigate contemporary views held by practitioners and educators on internal communication curricula.

\section{Social implications}

Social and management implications are discussed including a call for the reinstatement of internal communication in globally influential public relations education frameworks.

\section{Originality / value}

The discipline of internal communication is still understudied which is surprising given its impact on organisational effectiveness. Furthermore, little previous attention has been paid to the history of internal communication education. This article tackles that void, finds inconsistent treatment of the discipline in education frameworks over time, and contributes discussion on why these inconsistencies have occurred. 


\section{Keywords}

Internal communication

Employee communication

Public relations history

Public relations education

Employee engagement

\section{Article classification:}

Research Paper (using the historical research approach) 


\section{Article}

\section{Introduction}

For decades public relations and communication management educators and practitioners have been striving to develop education programmes to contribute to professional development. Historical issues of professionalism and public relations education have previously been considered (Jones 1981; Hainsworth 1993) and there is recognition that education plays an important role in professionalization (Pieczka \& L'Etang 2006). Internal communication is arguably one of the most important aspects of communication management and public relations practice. Internal communication consistently appears in the top five most pressing issues for European communication practice (European Communication Monitor 2009, 2010, 2011), it is highlighted among the key functions in USA practice (Goodman, Genst, Keller, Cayo and Gouy 2011). Furthermore, the results of a global study demonstrate that internal communication and employee engagement are among the key issues of concern for public relations leaders world-wide (Zerfass, Linke and Rottger 2014). Indeed, Zerfass et al. (2014) report that improving employee engagement through internal communication relates to three of the top ten issues highlighted in their global leadership survey. Clearly, these issues have internal communication and organisational effectiveness implications. The three issues are: 'improving employee engagement and commitment; finding, developing and retaining top talent; and meeting communication needs in diverse cultures in global organizations' (p.72). However, these authors observe that despite its relevance, internal communication is still understudied by communication scholars and they call for further research to develop new approaches to internal communication in the digital age. This article contributes one response to that call with a historical analysis of the treatment of internal communication in public relations education frameworks. This is a valuable contribution since little previous attention has been paid to the history of internal communication education. Public relations education has been subject to historical analysis in the past (e.g. Wright 2011), but the current article is the first to contribute a historical analysis of internal communication education, thus it opens a new line of inquiry into public relations history. This is a timely contribution given the recognition of internal communication as an important area of practice, indeed it is surprising that insufficient scholarly attention has yet been paid to internal communication education.

\section{Conceptual framework and literature review}

This section considers the historical research approach, defines the concept of internal communication as a facet of strategic public relations, discusses the extent to which public relations and communication management is considered a profession, and reflects on the nature of knowledge in the context of internal communication practice. It concludes with research objectives 
for the article's study of the treatment of internal communication in globally influential public relations education frameworks.

\section{Historical research}

The Journal of Communication Management (JoCM) has previously published articles on the history of public relations and the history of public relations education, this historical study of internal communication education contributes to that vein of research. However, some readers may be relatively unfamiliar with the historical research approach, so this section provides relevant background. The JoCM recognises the value of historical research having published historical research in the past, including two special editions on public relations history; the first in 2008 (Vol. 12 No. 4), and the second in 2011 (Vol. 15 No. 3). Historical research is a relatively recent research genre within the public relations and communication management discipline. Watson (2011a) notes that the JoCM 2008 special issue was the first time an international academic journal had devoted an entire scheduled edition to the history of public relations. Within the genre, the history of public relations education has been described as a relatively small but growing field within international public relations scholarship (Gleeson 2014). Watson (2011a) called for developments in public relations scholarship including building a cohort of public relations historians with expertise in archival research. Historical research is understood here as research that examines past events to arrive at an account of what happened (Johnson and Christensen 2014) and enable reflection on contemporary implications. Surveys, interviews and focus groups have been usefully employed in previous non-historical research projects relating to public relations education (Hon, Fitzpatrick and Hall 2004). However, since historical research must deal with data that already exists (Cohen, Manion and Morrison 2000), surveys are not appropriate for this research approach. Historical methodology often involves the analysis of documents, some held in archives (Daymon and Holloway 2011). Gleeson (2014) observes that historical research involves analysis of archival and published materials including publications from professional associations. This paper offers a contribution in that regard since it provides historical analysis of the treatment of internal communication education using a well-defined sample of material contained in the archives of two professional bodies.

\section{Internal communication}

Previous work has discussed and debated the definition of internal communication (Welch and Jackson 2007, Tkalac Verčič, Verčič and Sriramesh 2012). In line with Welch and Jackson (2007), internal communication is understood here as the strategic management of interactions and relationships between stakeholders at all levels within organisations. Internal communication varies 
from informal chat among colleagues, to formal corporate communication to all employees from senior executives. Between these two ends of the internal communication continuum there is a range of formal and informal communication via a variety of methods, involving individual employees in teams and in project groups, and between staff and line managers. One framework for appreciating this diversity is an internal communication matrix consisting of four internal communication dimensions: line management; team peer; project peer; and, internal corporate communication (Welch and Jackson 2007, Welch 2012). All four dimensions hold challenges for practice and for research. This article is principally concerned with internal corporate communication, which relates to communication between senior managers and all employees. Welch and Jackson (2007) position internal corporate communication within strategic public relations. The goals of internal corporate communication include promoting: commitment to the organisation; understanding of the organisation's evolving aims; a sense of belonging to the organisation; and, awareness of the organisation's changing environments.

Internal communication is emerging as a fast developing area of communication practice (European Communication Monitor 2009, 2010, 2011; Goodman et al. 2011). To build greater credibility and to make positive strategic contributions to organisational effectiveness, internal communication practitioners need to develop specialist knowledge and skills so they can meet the needs of diverse internal audiences and contribute to organisational success. Therefore, this article will examine influential public relations education frameworks to ascertain the extent to which they include internal communication and contribute to the professionalization of this important discipline.

\section{Professionalization}

The status of public relations as a profession has been debated for decades (Jones 1981; Hainsworth 1993; Pieczka \& L'Etang 2006). The debate has included misgivings about the value of professionalization in public relations (Steiner 2001) and discussion of differing perspectives of professionalism (van Ruler 2005). On the one hand, public relations, and by implication its component disciplines including internal communication, is already considered a profession by some. For example while Valin, Gregory and Likely (2014) acknowledge the professionalism debate, they repeatedly refer to the profession in their paper on the historical development of the Global Alliance for Public Relations and Communication Management. On the other hand, since public relations does not involve the strictly regulated, closed practices associated with longestablished traditional professions such as law and medicine, it cannot be classed as a profession in the strictest sense of the word. Given this, some consideration of the nature of professions and the position of public relations and internal communication is required. 
Professions have been subject to scholarly work for generations, with an extensive body of literature in sociology (Abbott 1988, Macdonald 1995). Professions have been studied from various perspectives including: identifying traits which set professions apart from other occupations; the professionalization process, characterised by stages in the natural history of professionalism; and, the power approach focussed on ways in which professions achieve social approval and autonomy (Pieczka and L'Etang 2006). Professionalization has been characterised as a process of socialisation in which members subscribe to values and beliefs nurtured by professional groups via training processes (McKenna 2012).

Among the professional groups dedicated to improving public relations practice, two have been particularly influential on global public relations education, the International Public Relations Association (IPRA) and the Commission on Public Relations Education (CPRE). The IPRA was founded in 1955 and is described by Sharpe (2005) as the world's only truly international public relations professional organisation. Sharpe notes that fourteen IPRA gold papers have been published, and asserts that those on public relations education are among the gold papers with the greatest impact on global developments. The CPRE was formed in 1973 (CPRE 1975), was cosponsored by the Public Relations Society of America and the Association for Education in Journalism (Plank 2005a), and issued a first report in 1975 (Grunig and Hunt 1984). A series of commissions comprised of academics and practitioners were appointed to advise on the content of public relations education courses. The CPRE's influence is underlined by the inclusion of the entire Port of Entry report (CPRE 1999) as an appendix to the Heath (2005) encyclopaedia of public relations. That report is widely referenced in works on public relations education internationally (for example in Rawel 2002; Xifraa and Castillo 2006; van Ruler 2005). Sriramesh (2002) observes that the recommendations of the CPRE affected curricula globally and notes the consequent predominant American influence on public relations education around the world. Likewise, Plank (2005a) remarks that the CPRE's work has worldwide distribution and impact.

Given the global impact these two organisations have on public relations education, material produced by IPRA and CPRE has been selected for historical analysis in this study since these organisations influence fundamental knowledge taught to practitioners. Analysing material produced by these bodies in this study enables consideration of the link between attempts to professionalise public relations practice and the extent this professionalization has included internal communication in public relations curricula. The historical research reported in this paper seeks to 
explore the extent to which specialist internal communication knowledge has been recognised in public relations education frameworks.

\section{Knowledge}

Access to a specialised body of knowledge is a core element associated with professional status (Meyer and Leonard 2014) and one of the distinctions between occupations and professions. Professional bodies, such as those mentioned in the preceding section, seek to influence the knowledge held by and taught to members of their profession. The nature of knowledge has been reflected upon for millennia. Knowledge can be conceptualised in various ways including the ancient philosophical definition of knowledge as justified true belief, although this definition has itself been challenged (Gettier 1963). Kolb, Lublin, Spoth and Baker (1986) argue that access to knowledge, as well as relationship networks, is key to strategic management development and acknowledge the role of higher education. Likewise, the authors of the International Association of Business Communicators (IABC) sponsored Excellence Project acknowledge that universities play an important role in the long-term diffusion of the knowledge required to achieve excellence in communication practice (Dozier, Grunig and Grunig 1995). They single out higher education among six other knowledge acquisition strategies as a means of acquiring in-depth knowledge. The other strategies are: knowing the business; self-study; professional association seminars; mentoring; department training; and, accreditation. They log advantages and disadvantages of each of the strategies and note that while higher education is time-consuming, it has the advantage of providing in-depth knowledge.

Pieczka and L'Etang (2006) emphasise the continuing contribution of education in the process of achieving legitimacy and professional status for public relations practice. Specialist education is a fundamental requirement of all professions, since it provides professionals with a distinct knowledge base. Therefore, the content of public relations education frameworks merits examination from an internal communication perspective.

\section{Research aim}

Since internal communication has clear implications for organisational effectiveness, internal communication managers need access to pertinent knowledge to assist their work. To contribute to thinking on internal communication education, this article investigates the treatment of the important discipline of internal communication in globally influential public relations education frameworks over time. This historical study seeks to uncover valuable findings to assist in the development of contemporary public relations curricula and secure a renewed focus on the pressing 
issue of internal communication. In investigating the treatment of the discipline of internal communication in globally influential public relations education frameworks over time, this research aims to contribute insight to this still under-studied discipline. Developing this insight is important since it has the potential to inform future professional development programmes. It is significant because little previous attention has been paid to the history of internal communication education and this research aims to address that gap.

To accomplish these aims the study:

- Locates globally influential public relations education frameworks.

- Assesses how the important discipline of internal communication has featured in globally influential public relations education frameworks over time.

- Critically analyses the treatment of internal communication and discusses possible influences and their implications.

The results of the historical analysis will show how internal communication has featured in a number of globally influential public relations education frameworks over time, with a view to identifying issues relevant to contemporary practitioners and educators.

\section{Methodology}

A historical research approach is used in this study to analyse reports and archival documentation. Daymon and Holloway (2011) provide helpful guidance for historical research. They describe public relations historical research as important but still embryonic and identify two distinct strands: $P R$ history, which reconstructs the role of communication activities in lives and past contexts; and PR thought history, which traces and interprets ideas, theories, or schools of thought about phenomena. The study presented in this article is a thought history, focusing on tracing the treatment of internal communication within public relations education frameworks. Daymon and Holloway (2011, p. 192) advise historical researchers to reflect on their individual stance as: 'The collusion of the researcher in the research process is a core aspect of historical research.' Therefore, it is important for researchers to reflect on their motivations, and to examine assumptions and influences on how they view and shape historical accounts. In this case, the researcher is an academic who previously worked in communication management and found internal communication one of the most interesting and challenging aspects of communication practice. Consequently, this article is influenced by a desire to contribute research with the potential to assist internal communication practice. 
Daymon and Holloway (2011) advise that source materials for historical studies are mainly written or visual documents often found in archives and collections held by organisations including professional associations, with oral memories and personal commentaries being other important sources. Daymon and Holloway (2011, p. 197) counsel that: 'Data sources should not be taken on face value but critically scrutinized.' Archival research poses a number of challenges to public relations and communication management researchers and methodological issues relating to archival research are discussed in the data sources section which follows.

\section{Data sources}

Rowlinson (2004) argues that the historical analysis of company documents is an important but under-used qualitative approach in organisational studies. Applied to professional bodies, this highlights a need to access document collections to conduct historical analysis. As mentioned above, two professional bodies (IPRA and CPRE) were selected as the focus of this study because of their global influence. Accordingly, IPRA and CPRE document collections were consulted for this study. Rowlinson (2004) notes the acceptability of intensive analysis of a limited selection of documents. The selected collections relate to public relations education frameworks, and the data sources analysed in the study are shown in Table 1 in two clusters. The first cluster consists of IPRA material and represents the earliest data identified as relevant for this study. The majority of this material was accessed at the International History of Public Relations Archive in Bournemouth (see Watson 2011b for a summary of the archive content). The second cluster consists of CPRE material. It is the most recent relevant material identified for this study, and it was accessed via the CPRE online publication collection (www.commpred.org/reports/). Background information on the IPRA and CPRE is provided in the findings sections that follow.

As mentioned in the discussion of the concept of professionalization, Sharpe (2005) notes that the IPRA gold papers on public relations education have had global impact but unfortunately, Sharpe does not list the relevant papers. Watson's (2011b) IPRA archive overview lists a series of Gold Papers from 1971-2008 and identifies two papers on education (No. 4 and No. 7). A further paper (1976, No. 2) was identified via a reference in the CPRE (1999) report, and a copy was located within a collected volume in the IPRA archive. A fourth education gold paper (No. 12) was indicated via a reference listed in work relating to UK public relations practice by Chan (2004). However, this document could not be found in the IPRA archive. Archive incompleteness is a recognised limitation of historical archival research in public relations, necessitating the need for researchers to work with available data to some extent, whilst being open about the limitations of data sources (Fitch 2014; L'Etang, 2008). Another option is for the historical researcher to turn 
detective and attempt to track down missing material via other outlets. That approach was taken in the current study and the fourth (IPRA 1997) education gold paper was subsequently accessed via application to the British Library. The importance of fastidiousness in gathering original source material was highlighted in the course of this study since an internet search yielded reproductions of the gold papers. Some of the reproductions carried a modern version of the IPRA logo, but they all featured multiple typographical errors, suggesting they may have been produced via optical character recognition software. In addition, the reproductions were incomplete, for example appendices present in the originals were missing from the reproductions. Therefore, the reproductions were deemed unsuitable for historical analysis and the original IPRA sources were analysed for this study.

Table 1: Data sources

\begin{tabular}{|c|c|c|}
\hline $\begin{array}{l}\text { Archive / } \\
\text { collection }\end{array}$ & Data sources & $\begin{array}{l}\text { No. of } \\
\text { pages }\end{array}$ \\
\hline \multirow{4}{*}{$\begin{array}{l}\text { International } \\
\text { Public Relations } \\
\text { Association }\end{array}$} & $\begin{array}{l}\text { - IPRA (1976) Gold Paper No. } 2 \text { Public relations education } \\
\text { worldwide. }\end{array}$ & 25 pages \\
\hline & $\begin{array}{l}\text { - IPRA (1982) Gold Paper No. } 4 \text { A Model for public relations } \\
\text { education for professional practice. }\end{array}$ & 41 pages \\
\hline & $\begin{array}{l}\text { - IPRA (1990) Gold Paper No. } 7 \text { Public relations education: } \\
\text { Recommendations and standards. }\end{array}$ & 36 pages \\
\hline & $\begin{array}{l}\text { - IPRA (1997) Gold Paper No. } 12 \text { The evolution of public } \\
\text { relations education and the influence of globalisation: Survey } \\
\text { of eight countries. }\end{array}$ & 72 pages \\
\hline \multirow{4}{*}{$\begin{array}{l}\text { Commission on } \\
\text { Public Relations } \\
\text { Education }\end{array}$} & $\begin{array}{l}\text { - CPRE (1999) Public relations education for the } 21^{\text {st }} \text { century: A } \\
\text { port of entry. }\end{array}$ & 33 pages \\
\hline & $\begin{array}{l}\text { - CPRE (2006) Public relations education for the } 21^{\text {st }} \text { century: } \\
\text { The professional bond. }\end{array}$ & 92 pages \\
\hline & $\begin{array}{l}\text { - CPRE (2010) A first look: An in-depth analysis of global } \\
\text { public relations education. }\end{array}$ & 28 pages \\
\hline & $\begin{array}{l}\text { - CPRE (2012) Standards for a master's degree in public } \\
\text { relations: Educating for complexity. }\end{array}$ & 48 pages \\
\hline
\end{tabular}

\section{Data analysis} Methods

The data sources were thematically analysed to identify specialist internal communication education elements. King's (2004) thematic template analysis approach was employed to guide the data analysis. Rowlinson (2004) recommends this approach for the historical analysis of organisational documents. Likewise Easterby-Smith, Thorpe and Jackson (2012) and Saunders, Lewis and Thornhill (2012) highlight the usefulness of template analysis in business and management research. The template approach shares elements of Miles and Huberman's matrix analysis process (1994). Accordingly, initial deductive template analysis was conducted on themes observed in 
relevant literature (e.g. staff, employees, personnel, communication inside organisations, employee publics, employee relations, industrial relations). Inductive analysis identified emergent themes (e.g. human resources, specialisation) that were then added to the template. The results of the analysis are provided next alongside background to the professional bodies.

\section{Analysis}

\section{IPRA overview}

As mentioned earlier, the IPRA was formed in 1955. In 1982 the IPRA described itself as a: 'worldwide professional and fraternal organisation which serves as a catalyst in the continuing development of the highest possible standards of public relations ethics, practice and performance' (IPRA 1982, inside front cover). The global aspirations of the organisation are clear from this description. In 2014, the IPRA website assumes public relations has the status of a profession and describes the organisation's role thus: 'Today IPRA constitutes the most genuinely international grouping of public relations practitioners worldwide, active not only in promoting exchange of information and co-operation in every sector of the profession, but also in building a programme of professional development opportunities and other initiatives aimed at enhancing the role of public relations in management and international affairs' (IPRA 2014). The IPRA sources listed in Table 1 were analysed for this study and are considered next in chronological order.

\section{IPRA (1976) Gold Paper No. 2}

The earliest IPRA gold paper relevant to public relations education (1976, Gold Paper No. 2) was authored by the IPRA's Professional Standards Committee Chairman, Professor Albert Oeckl. The paper is entitled: Public relations education worldwide, and includes specific internal communication education frameworks. Thematic analysis identified explicit inclusion of internal communication in this gold paper. The paper provides three recommended sample curricula, at university, intermediate and practical levels, and internal communication was clearly featured within two of these curricula. 'Internal information and communication' is featured in the intermediate level sample curricula example from Switzerland (IPRA 1976, p. 21) and encompasses several aspects of internal communication including concept, objectives and methods, written and verbal communication, internal events and the flow of information. The practical curriculum from Germany includes 'internal corporate public relations' (IPRA 1976, p. 23). Additionally, the paper includes recruitment of personnel and hiring new employees. So this gold paper indicates clear recognition of internal communication within the public relations education frameworks it highlighted. 
IPRA (1982) Gold Paper No. 4

Gold Paper No. 4 (IPRA 1982) was prepared in 1980-81 by the IPRA Education and Research Committee in collaboration with the IPRA International Commission on Public Relations Education. It is entitled A model for public relations education for professional practice, and features an introduction by IPRA Education and Research Committee Chairman Göran Sjöberg. Thematic analysis of Gold Paper No. 4 found explicit and implicit recognition of internal communication within the paper. Internal communication is included in curriculum recommendations. Three aspects of internal communication are implied in a list of 15 public relations practice areas (promoting goodwill with staff, improving industrial relations, attracting good personnel and reducing labour turnover). The paper acknowledges the growth of concern about a number of issues including employee safety. It recognises the need for public relations to coordinate with organisational functions including personnel, and recommends the inclusion of human relations in public relations education programmes. However, the context indicates that overall human relations is probably meant here, rather than employee relations.

\section{IPRA (1990) Gold Paper No. 7}

The 1990 gold paper (IPRA 1990) Gold Paper No. 7 is entitled: Public relations education: Recommendations and standards, and includes an introduction by IPRA International Commission on Public Relations Education Chairman Sam Black. Gold Paper No. 7 repeats substantial parts of Gold Paper No. 4. Sections of text from the earlier paper are incorporated, some with additional commentary. Promoting goodwill with staff, improving industrial relations, attracting good personnel and reducing labour turnover are again included in a listing of public relations practice areas. A section on evaluation highlights employee exit interviews as one of twelve methods of programme effectiveness along with communication audits (which can be employed internally and externally).

This gold paper contributes a recommended curriculum (whilst noting that considerable variation is possible within general frameworks) based on a 1987 CPRE study involving 1,500 public relations practitioners and academics. Respondents were asked to rate curriculum topics from 1 (not essential) to 7 (most essential). There were 70 topics (rated between 6.51 'Planning, Writing, Producing and Delivering Print Communication to Audiences' and 4.50 'International Public Relations'). A number of internal communication topics were included in the recommended curriculum (ratings in parenthesis): Employee relations (6.00), Employee/Internal Communication (5.87), Continuing Programmes - Personnel, Safety, Suggestions etc. (5.70), Employee Audits (5.43). The survey findings were also presented in clusters. Employee relations was ranked at 
number three of eight public relations specialisations. Employee audits (part of Social Audits / Communication Audits - Employee Audits) ranked fifth out of ten public relations research areas. Continuing Programmes - Personnel, Safety, Suggestions etc. ranked second of seven public relations action / implementation areas. Employee / internal communication ranked third in a list of 17 public relations communication topics. Clearly, the 1990 paper indicates internal communication as an essential curriculum topic. Furthermore, this gold paper includes typical public relations curricula from education programmes around the world and internal communication topics feature within three of them: employee relations (New Zealand); employee publics, and public relations within organisations (India); and the management of change (Britain). Organisational communication was mentioned in the USA example, but it is unclear as to whether this refers to internal communication per se or to communication as a phenomenon within organisations.

\section{IPRA (1997) Gold Paper No. 12}

The 1997 gold paper is the largest of the four IPRA data sources and the final IPRA paper on public relations education identified in this study. It is entitled: The evolution of public relations education and the influence of globalisation: Survey of eight countries, and contains a foreword by IPRA President, Roger Hayes, and a preface by the Steering Committee Chairman, Takashi Inoue. Promoting goodwill with staff, improving industrial relations, attracting good personnel and reducing labour turnover are again included in a listing of parameters of the public relations function. Examples of typical professional development courses from various countries are provided and they include internal communications (USA) and employee relations and communication (UK). In a discussion of the impact of globalisation, the paper highlights the importance of employee audiences. It reports an American CEO's views on the importance of internal communication including the belief that a company will have 70,000 ambassadors if its 70,000 employees understand the corporate objectives. The report claims: 'Even if it is impossible to realise 100 percent employee satisfaction, internal communication has an important part to play in increasing the level of satisfaction' (p. 59). In addition, the IPRA (1997) paper discusses perspectives on professional development and lists employee communication in observations about the increasingly specialised nature of public relations.

The analysis of the four IPRA education gold papers above demonstrates that internal communication had a clear and consistent profile in the IPRA's globally influential public relations education gold papers. Notably, the IPRA stopped publishing education gold papers in 1997. However, the CPRE published a number of reports on public relations from 1999. The analysis will 
now focus on the subsequent globally influential work on public relations education by the CPRE listed in Table 1 and begins with an overview of the CPRE.

\section{CPRE overview}

The CPRE was established in 1973 and the original goals of the organisation were to examine the requirements of professional practice to relate them to educational standards, and to make recommendations on improving public relations education to meet the needs of the profession and improve practice (CPRE 1975). The CPRE was formed by professional bodies to examine issues related to public relations education. Plank (2005b) notes that the Public Relations Society of America (PRSA) and the Public Relations Division of the Association for Education in Journalism and Mass Communication sponsored the CPRE's work. Plank describes the CPRE as being composed of academics and practitioners who conduct research on the educational requirements of the public relations field. The CPRE recommendations on standards of public relations education have been adopted by the PRSA as the basis for their charter recognition of the quality of education provision.

The CPRE website (2014) describes the organisation as being: 'composed of public relations educators and practitioners representing 15 professional societies in PR and related fields of communications.' The same source describes the CPRE mission: 'The Commission seeks to establish benchmarks for teaching public relations that are current, research-based, sensitive to culture and language and applicable to preparing public relations students for a career in practice, research or teaching. The Commission chooses projects from the full spectrum of activity in the education field including researching and identifying factors that encourage or deter students from choosing a career in public relations.'

Grunig and Hunt (1984) note that the first commission studied public relations education in 1975 and a second in 1981. Plank (2005a) describes the third commission's 1999 report as having worldwide distribution and impact. Since this study is concerned with global influences on internal communication education the CPRE's 1999 report will be considered next followed by the further three reports $(2006,2010,2012)$. All these reports were accessed via the CPRE online report collection (www.commpred.org/reports/).

\section{CPRE (1999)}

The CPRE (1999) Public relations education for the $21^{\text {st }}$ century: A port of entry report has no named author or editor. The report recommends a minimum of five courses in public relations 
studies for an undergraduate degree in the discipline. Explicit inclusion of internal communication was found via the template analysis process. The report's introduction highlights the growing importance of communicating with internal as well as external publics among key issues for public relations. In a section outlining the background to the development of public relations practice, the report (CPRE 1999, p. 7) notes that the practice evolved in response to the needs of employers and clients to include: 'internal communications (publications, special events and awards programs) to support efforts to enhance employee productivity and commitment.'

The report recommends specific content areas for inclusion in undergraduate public relations programmes and many of them are implicitly related to internal communication. The report also makes explicit recommendations relating to the discipline. It recommends that the content of public relations writing and production courses address employee and internal communication amongst a number of other elements. Additionally, employee audits are included within recommendations for public relations research, measurement and performance evaluation. It also recommends that Master's degree courses have additional content including building relationships with internal and external audiences within a public relations management course.

\section{CPRE (2006)}

The CPRE (2006) report is entitled: Public relations education for the $21^{\text {st }}$ century: The professional bond, and is edited by Judy VanSlyke Turk. The report outlines results and recommendations arising from five USA research projects. The report acknowledges the importance of internal communications and includes the discipline in its recommendations for public relations undergraduate and graduate courses.

The report lists the increasing importance of internal audiences amongst trends affecting public relations practice. It highlights the growing importance of internal communication with the comment: 'the ability to incorporate the internal audience into public relations planning and communication is increasingly required in meeting the challenges and opportunities presented to an organization...human resources departments increasingly are expecting public relations to manage employee communications' (CPRE 2006, p. 45).

Like its 1999 predecessor, the 2006 report highlights internal communication for inclusion in undergraduate and graduate programmes. The report repeats recommendations that the content of undergraduate public relations writing and production courses include employee and internal communication. Likewise, the report recommends the inclusion of employee audits within public 
relations research measurement and evaluation courses. Furthermore, it recommends inclusion of relationship-building with internal/external publics within graduate public relations management courses.

\section{CPRE (2010)}

The CPRE 2010 report authored by Elizabeth Toth and Linda Aldoory is entitled: A first look: An in-depth analysis of global public relations education. The report describes initial findings of a CPRE study to document how public relations is taught at undergraduate and graduate levels in 20 countries around the world. Systematic template analysis found that, unlike the IPRA gold papers and the earlier CPRE reports analysed above, the 2010 report did not include any mention of either employee or internal communication. 'Organizational communication' is included in a table of courses taught by participants (CPRE 2010 p. 21) but there is no indication as to whether this refers to internal communication per se, or communication as a phenomena.

The 2010 CPRE report found that the CPRE (2006) five course model standard had been widely adopted in the 20 countries they included in the study. As detailed above in the discussion of the CPRE 1999 and 2006 reports, this standard includes internal communication elements. So, whilst not spelt out explicitly, internal communication is implicitly included.

\section{CPRE (2012)}

The CPRE (2012) report is entitled Standards for a master's degree in public relations: Educating for complexity, and does not include a named author or editor. It contains a preface and acknowledgements section saluting the work of the group of people involved in the production of the report on behalf of the CPRE. The report refers to the global influence of the CPRE's previous reports and recommendations on public relations education. It notes that graduate education has received cursory attention in the past, therefore necessitating the report's focus on master's level education.

The report's recommended curriculum for master's degrees in public relations education identifies more than 50 content areas. Template analysis confirms that the report does not include specific mention of internal or employee communication. Neither topic is included in the extensive list of curriculum content areas provided in the report. Some of these curriculum content areas are implicitly related to internal communication for example: relationship management; distinctions between types of publics; and crisis communications. However, there is no explicit mention of employees or internal communication. The omission of specific mention of internal or employee 
communication in the most recent CPRE report on public relations education is problematic given the acknowledged increasing importance of this branch of communication practice. Educators relying on the most recent CPRE reports may underestimate the importance of internal communication education and therefore omit it from their curricula.

The historical analysis of the data sources has revealed a diminishment in the emphasis on internal communication in public relations education frameworks and leads to the question addressed in the discussion that follows: Why has internal communication disappeared from the recent frameworks?

\section{Discussion}

The analysis above demonstrates that internal communication has featured prominently in globally influential public relations education frameworks over time (IPRA 1976, 1982, 1990, 1997 and CPRE 1999, 2006), was implied in the CPRE (2010) report, but excluded from the most recent CPRE (2012) report. Consequently the analysis demonstrates inconsistent treatment of internal communication in education frameworks over time and raises questions about why internal communication has been excluded from the most recent public relations education framework.

Several alternative explanations are possible, the first being that a simple oversight has occurred. The sources considered above are the result of complex projects looking at public relations education and involve the efforts of large numbers of dedicated academics and practitioners. It is possible the later CPRE (2010 and 2012) reports simply overlooked internal communication. However, given the emphasis placed on the growing importance of internal communication in the CPRE (2006) report, this seems remarkable, so alternative possible explanations need consideration.

\section{Generalists dominate specialists?}

As observed in the analysis, the IPRA (1997) gold paper includes employee communication in a discussion of the increasingly specialised nature of public relations. However, an ongoing debate has been observed in public relations literature relating to the merits of generalists versus specialists (for example Wakefield and Cottone 1986, van Ruler 2005, Gregory 2012). This debate is often framed within discussion of the professionalization of public relations practice. Broadly, the generalist school of thought argues that public relations practitioners should have wide general knowledge and skills applicable to all branches of the practice. Conversely the specialist school of thought maintains that general knowledge and skills should be supplemented with in-depth knowledge relevant to particular areas of practice such as internal communication. 
Clearly, the historical analysis presented in this paper is influenced by the specialist school of thought. Therefore reflection is required; maybe only generalists are needed, and specialist internal communication knowledge is not required. Arguably, taking a generalist view could hamper the internal communication discipline from developing as a profession. This argument can be examined from the standpoint of traditional professions. The family doctor would not necessarily be the first choice of clinician if a person needed intricate brain surgery. Here, the patient might prefer a surgeon with specialist knowledge of the relevant branch of medicine. Applied to communication, organisations may expect to have the option to call on communication managers with specialist internal communication knowledge and insight as well as general communication practitioners.

\section{Perception that there is no suitable body of internal communication knowledge?}

A perception that there is a lack of suitable internal communication knowledge frameworks would be a barrier to efforts to include the discipline in public relations education frameworks. However, this would be an erroneous perception as specific internal communication knowledge frameworks exist. As shown in the analysis above, internal communication curricula topics have been in evidence since the 1970s. In addition, there are a number of other frameworks including: a framework developed by a consortium of professional bodies (CIB/ICA/IABC 2004, cited in Smith and Mounter 2008); an empirically based internal communication knowledge framework (Welch 2013); and professional body qualification curricula such as those offered by the UK's Chartered Institute of Public Relations (CIPR 2014) and the Public Relations Institute of Ireland (PRII 2014).

\section{Consultancy influence subsuming in-house communicators?}

Another alternative explanation concerns consultancy and agency interests vying with in-house communicator influences. It is possible that members of one group might subsume the voice of the other on education commissions. This is an important issue since previous research (Wakefield and Cottone 1987) shows that agency public relations practitioners rate the importance of internal communication (employee / labour communication) considerably lower (29 $9^{\text {th }}$ of 39$)$ than in-house practitioners $\left(7^{\text {th }}\right)$. That paper reported the results of a survey which asked communicators to rate the importance of knowledge / skill elements on a four point scale (4=Very important; 1=Moderately unimportant). That study found: 'Organizations placed significantly more importance than did agencies/firms on the knowledge and skill areas of employee/labor relations' (p. 28). The agency practitioners rated the importance of internal communication considerably lower $\left(29^{\text {th }}\right.$ of 39 ; M2.88) than in-house practitioners $\left(7^{\text {th }} ;\right.$ M3.34). This result may be influenced by a greater external than internal communication focus among public relations consultancies. There is a possibility that public relations education commissions are more strongly influenced by agency voices. If so, a 
dominating focus on external communication issues may result, at the expense of internal communication. Likewise, growing concern with externally focused issues such as branding and reputation management might have reduced attention on internal communication.

\section{Conclusions}

The historical analysis reported in this article found that internal communication has been recognised as an important aspect of practice, meriting inclusion in public relations education frameworks. It also found that recent frameworks have excluded internal communication. A number of alternative explanations for this are considered above including: the possibility that a simple oversight has occurred; the generalist school of thought dominating the specialist school; an erroneous perception of a lack of internal communication knowledge frameworks; externally focused issues such as branding and reputation management reducing attention on internal communication; and the possibility that externally focused agency practitioner influences subsume those of in-house practitioners. Whatever the reason for the exclusion, the reinstatement of internal communication in globally influential public relations education frameworks is necessary. Limitations and methodological implications are considered next alongside practical, research, and social implications of the research.

\section{Practical implications}

This article has practical educational and methodological implications. To truly move toward becoming a profession, the public relations discipline needs a specialist as well as a generalist knowledge base. Internal communication is a key specialist area of strategic public relations. The ongoing specialist and generalist debate may have begun in an effort to prevent encouragement of very narrow skill sets such as publicity or media relations, in favour of a well-rounded education. That is laudable, provided it does not hamper development of education in important specialist disciplines like internal communication. A pedagogic implication arises from this, public relations educators need access to internal communication education frameworks to inform their teaching and research. Specialist frameworks such as those listed in the discussion above can highlight options for interested academics to consider as they prepare their teaching. However, educators relying on the most recent CPRE reports may inadvertently underestimate the importance of internal communication education because of its exclusion, and therefore omit it from their curricula. This study may serve to alert educators relying on these frameworks of the danger of inadvertently overlooking internal communication in their teaching. 


\section{Further research}

This article emphasises that internal communication education is an important issue for future research. Researchers could use survey strategies or qualitative approaches to build on the historical research reported in this article to investigate contemporary views held by practitioners and educators on internal communication curricula. For example, future studies could complement historical research by surveying educators and managers on the content of internal communication courses to add to existing (Welch 2013) empirically based frameworks. In addition, internal communication education could be researched via historical studies in national contexts. The following section includes further recommendations for research from a methodological perspective.

\section{Limitations and methodological implications}

Limitations are inherent in all studies, and this historical account is limited to English language data sources. Nevertheless, these sources are credited with international influence. Despite this limitation, the article has useful implications for research methodology. Firstly, it highlights the value of archival research for historical studies in public relations. Secondly, it emphasises the importance of securing access to original source material. As noted in the study, using reproductions of sources could result in researchers working with incomplete and misleading material. Furthermore, the template analysis process (King 2004) used here assisted in the rigorous analysis of the source material. It is thus recommended as a useful additional approach to qualitative analysis for public relations and communication management researchers. In particular, the template approach assists in studies, like this historical study, which conducts reiterated research on a number of themes across several data sources. The template approach assists analytical effectiveness and rigour and could be an asset to future public relations and communication management research work.

\section{Social and management implications}

This article has a number of potential social and management implications. First, it invites public relations professional bodies and education commissions to reconsider the specialist-generalist debate and consider barriers to the diffusion of internal communication knowledge. Therefore, it has potential to inform education policies and protocols. Next, the research may encourage professional bodies like the IPRA to follow the CPRE's good practice by providing freely available, online open access to an archive of its gold papers. 
One management implication of the study is to encourage communication managers to reflect on the emphasis they place on internal versus external communication efforts. Furthermore, the article calls for the reinstatement of internal communication in globally influential public relations education frameworks. Reinstatement would contribute to the development of future communication managers with in-depth knowledge of internal communication. These managers would be better able to contribute to organisational success via improved workplace communications. This in turn will benefit employees for whom poor internal communication can be a source of work stress and dissatisfaction. It will also benefit organisations seeking to maximise employee engagement and organisational effectiveness.

Whatever the reasons for the disappearance of internal communication from public relations education frameworks over time, the discipline is too important to be excluded from future frameworks. Explicit inclusion of internal communication is necessary if these frameworks are to equip communication practitioners with the means to make valuable contributions to employee engagement, help build organisational effectiveness, and meet diverse employee communication needs. 


\section{References}

Abbott, A. (1988) The system of professions: An essay on the division of expert labor. Chicago. University of Chicago Press.

Chan, G. (2004) Priorities old and new for UK PR practice. In Oliver, S. (2004) Handbook of corporate communication and public relations, pp. 71-89. London. Routledge.

Chartered Institute of Public Relations (CIPR 2014) Chartered Institute of Public Relations. Available at: $\underline{w w w . c i p r . c o . u k}$. Accessed $9^{\text {th }}$ September 2014.

Cohen, L., Manion, L., Morrison, K. (2000) Research Methods in Education. London. Routledge. CPRE (1975) A design for public relations education. Public Relations Review Vol. 1 No. 3 pp. 5666. Accessed on: 21st August 2014.

CPRE (1999) Public relations education for the 21 st century: A port of entry. Commission on Public Relations Education. Available at: www.commpred.org. Accessed on: $30^{\text {th }}$ June 2014.

CPRE (2006) Public relations education for the $21^{\text {st }}$ century: The professional bond. Commission on Public Relations Education. Available at: www.commpred.org. Accessed on: $9^{\text {th }}$ December 2011.

CPRE (2010) A first look: An in-depth analysis of global public relations education. Commission on Public Relations Education. Available at: www.commpred.org. Accessed on: $28^{\text {th }}$ June 2012.

CPRE (2012) Standards for a master's degree in public relations: Educating for complexity. Commission on Public Relations Education. Available at: www.commpred.org. Accessed on: $19^{\text {th }}$ February 2014.

CPRE (2014) About the Commission. Commission on Public Relations Education. Available at http://www.commpred.org/about/. Accessed on: 29 $9^{\text {th }}$ August 2014.

Daymon, C., Holloway, I. (2011) Qualitative research methods in public relations and marketing communications. Abingdon. Routledge.

Dozier, D. M., Grunig, L. A., Grunig, J. E. (1995) Manager's guide to excellence in public relations and communication management. Mahwah. Lawrence Erlbaum.

Easterby-Smith, M., Thorpe, R., Jackson, P. R. (2012) Management research. London. Sage.

European Communication Monitor (2009, 2010, 2011) Results of an empirical survey. Brussels:

EACD, EUPRERA, (available at: www.communicationmonitor.eu). Accessed on: $25^{\text {th }}$ October 2015. 
Fitch, K. (2014) Professionalisation and public relations education: Industry accreditation of Australian university courses in the early 1990s. Public Relations Review. Vol. 40 No. 4 pp. 623-631.

Gettier, E. L. (1963) Is justified true belief knowledge? Analysis. Vol. 23 No. 6 pp. 121-123.

Gleeson, D. J. (2014) Public relations education in Australia, 1950-1975. Journal of Communication Management. Vol. 18 No. 2 pp. 193-206.

Goodman, M. B., Genst, C., Keller, A., Cayo, D., Gouy, S. (2011) CCI corporate communication practices and trends 2011: United States - Final report. New York. Corporate Communication International.

Gregory, A. (2012) UK Government communications: Full circle in the 21st century? Public Relations Review. Vol. 38 No. 3 pp. 367-375.

Grunig, J. E., Hunt, T. (1984) Managing public relations. New York. Holt, Rinehart and Winston. Hainsworth, B. E. (1993) Commentary: Professionalism in public relations. Public Relations Review. Vol. 19 No. 4 pp. 311-418.

Heath, R. (Ed.) (2005) Encyclopedia of public relations. Thousand Oaks. Sage.

Hon, L. C., Fitzpatrick, K. R., Hall, M. R. (2004) Searching for the "ideal" graduate public relations curriculum. Journalism and Mass Communication Educator. Vol. 59 No. 2 pp. 126-142.

IPRA (1976) Gold Paper No. 2: Public relations education worldwide. London. International Public Relations Association.

IPRA (1982) Gold Paper No. 4: A model for public relations education for professional practice. London. International Public Relations Association.

IPRA (1990) Gold Paper No. 7: Public relations education: Recommendations and standards. London. International Public Relations Association.

IPRA (1997) Gold Paper No. 12: The evolution of public relations education and the influence of globalisation: Survey of eight countries. London. International Public Relations Association. IPRA (2014) International Public Relations Association, available at: www.ipra.org Accessed 19th February 2014.

Johnson, R. B., Christensen, L. (2014) Educational research: Quantitative, qualitative, and mixed approaches. Thousand Oaks. Sage.

Jones, S. (1981) Foundation lecture: The individual pursuit of a profession. Public Relations Review. Vol. 7 No. 1 pp. 3-16.

King, N. (2004) Using templates in the thematic analysis of text. In Symon, G., Cassell, C. (Eds.) (2004) Qualitative methods and analysis in organizational research (pp. 256-71). London. Sage. 
Kolb, D., Lublin, S., Spoth, J., Baker, R. (1986) Strategic management development: Using experiential learning theory to assess and develop managerial competencies. Journal of Management Development. Vol. 5 No. 3 pp.13-24.

L'Etang, J. (2008) Writing PR history: Issues, methods and politics. Journal of Communication Management. Vol. 12 No. 4 pp. 319-335.

Macdonald, K. M. (1995) The sociology of the professions. London. Sage.

McKenna, E. (2012) Business psychology and organisational behaviour. Hove. Psychology Press.

Meyer, A. L., Leonard, A. (2014) Are we there yet? En-route to professionalism. Public Relations Review. Vol. 40 No. 2 pp. 375-386.

Miles, M. B., Huberman, A. M. (1994) Qualitative data analysis - an expanded sourcebook. Thousand Oaks. Sage.

Oeckl, A. (1976) Gold Paper No. 2: Public Relations Education Worldwide. International Public Relations Association. London.

Pieczka, M., L'Etang, J. (2006) Public relations and the question of professionalism. In L'Etang, J. \& Pieczka, M. (Eds.). Public relations: Critical debates and contemporary practice (pp. 265-78). Mahwah. Lawrence Erlbaum Associates.

Plank, B. (2005a) Public relations student society of America. In R. Heath (Ed.) (2005) Encyclopedia of public relations (pp. 700-704). Thousand Oaks. Sage.

Plank, B. (2005b) Public relations society of America. In R. Heath (Ed.) (2005) Encyclopedia of public relations (pp. 696-700). Thousand Oaks. Sage.

Public Relations Institute of Ireland (PRII 2014) Public Relations Institute of Ireland. Available at: www.prii.ie. Accessed $9^{\text {th }}$ September 2014.

Rawel, A. (2002) How far do professional associations influence the direction of public relations education? Journal of Communication Management. Vol. 7 No. 1 pp. 71-78.

Rowlinson, M. (2004) Historical analysis of company documents. In Symon, G., Cassell, C. (Eds.) (2004) Essential guide to qualitative methods in organizational research (pp. 301-312). London. Sage.

Saunders, M., Lewis, P., Thornhill, A. (2012) Research methods for business students. Harlow. Pearson.

Sharpe, M. (2005) International public relations association. In R. Heath (Ed.) (2005) Encyclopedia of public relations (pp. 439-442). Thousand Oaks. Sage.

Smith, L., Mounter, P. (2008) Effective internal communication. London. Kogan Page.

Sriramesh, K. (2002) The dire need for multiculturalism in public relations education: An Asian perspective. Journal of Communication Management. Vol. 7 No. 1 pp. 54-70. 
Steiner, C. J. (2001) How important is professionalism to corporate communication? Corporate Communications: An International Journal. Vol. 6 No. 3 pp. 150-156.

Tkalac Verčič, A., Verčič, D., Sriramesh, K. (2012) Internal communication: Definition, parameters, and the future. Public Relations Review. Vol. 38 No. 2 pp. 223-230.

Valin, J., Gregory, A., Likely, F. (2014) The Global Alliance for Public Relations and Communication Management: Origins, influences, issues and prospects. Public Relations Review. Vol. 40 No. 4 pp 639-653.

van Ruler, B. (2005) Commentary: Professionals are from Venus, scholars are from Mars. Public Relations Review. Vol. 31 No. 2 pp. 159-316.

Wakefield, G., Cottone, L. P. (1986) Education for the '80s and beyond. Public Relations Review. Vol. 12, No. 2 pp. 37-46.

Wakefield, G., Cottone, L. P. (1987) Knowledge and skills required by public relations employers. Public Relations Review. Vol. 13 No. 3 pp. 24-32.

Watson, T. (2008) Guest editorial. Journal of Communication Management. Vol. 12 No. 4 (no page number).

Watson, T. (2011a) Editorial: History of public relations special issue. Journal of Communication Management. Vol. 15 No. 3 (no page number).

Watson, T. (2011b) The archive of the International Public Relations Association: Contents and index. Retrieved from: http://microsites.bournemouth.ac.uk/historyofpr/files/2011/11/IPRA-ARCHIVE.pdf. Accessed 23rd February 2014. Bournemouth University, UK.

Welch, M. (2013) Mastering internal communication: Knowledge foundations and postgraduate education. Public Relations Review. Vol. 39 No. 5 pp. 615-617.

Welch, M., Jackson, P. R. (2007) Rethinking internal communication: a stakeholder approach. Corporate Communications: An International Journal. Vol. 12 No. 2 pp. 177-198.

Welch, M. (2012) Appropriateness and acceptability: Employee perspectives of internal communication. Public Relations Review. Vol. 38 No. 2 pp. 246-254.

Wright, D. K. (2011) History and development of public relations education in North America: A critical analysis. Journal of Communication Management. Vol. 15 No. 3 pp. 236-255.

Xifraa, J., Castillo, A. (2006) Forty years of doctoral public relations research in Spain: A quantitative study of dissertation contribution to theory development. Public Relations Review. Vol. 32 No. 3 pp. 302-308.

Zerfass, A., Linke, A., Rottger, U. (2014) The context for leadership in public relations: Key issues in the field. In Berger, B. K., Meng, J. (Eds.) (2014) Public relations leaders as sensemakers: A global study of leadership in public relations and communication management (pp. 63-79). New York. Routledge. 